\title{
Efficacy of Hot Water and Chlorine for Eradication of Cladosporium variabile, Stemphylium botryosum, and Verticillium dahliae from Spinach Seed
}

\author{
Lindsey J. du Toit, Vegetable Seed Pathologist, and Pablo Hernandez-Perez, Former Graduate Research Assistant, \\ Washington State University-Northwestern Washington Research \& Extension Center, Mount Vernon 98273-4768
}

\begin{abstract}
du Toit, L. J., and Hernandez-Perez, P. 2005. Efficacy of hot water and chlorine for eradication of Cladosporium variabile, Stemphylium botryosum, and Verticillium dahliae from spinach seed. Plant Dis. 89:1305-1312.

Cladosporium variabile, Stemphylium botryosum, and Verticillium dahliae are seedborne and seed-transmitted pathogens of spinach. Spinach seed treatments in $1.2 \% \mathrm{NaOCl}$ for 10 to 60 $\mathrm{min}$, or hot water $\left(40,45,50,55\right.$, and $\left.60^{\circ} \mathrm{C}\right)$ for 10 to $40 \mathrm{~min}$, were evaluated for eradication of these fungi from seed. C. variabile and $V$. dahliae were largely eradicated by chlorine treatment for $\geq 10 \mathrm{~min}$. Although chlorine treatment reduced the incidence of $S$. botryosum, this fungus was not eradicated after $60 \mathrm{~min}$ in chlorine. Seed germination was not affected adversely by chlorine treatment, even after $60 \mathrm{~min}$. In contrast, germination was reduced significantly by hot water treatment at $50^{\circ} \mathrm{C}$ for $\geq 30 \mathrm{~min}$ or 55 or $60^{\circ} \mathrm{C}$ for $\geq 10 \mathrm{~min}$. C. variabile was eradicated from seed treated in $40^{\circ} \mathrm{C}$ water for $10 \mathrm{~min}$. V. dahliae was eradicated from seed treated at $55^{\circ} \mathrm{C}$ for $\geq 30$ min or $60^{\circ} \mathrm{C}$ for $\geq 10 \mathrm{~min}$. S. botryosum was eradicated from a lightly infected seed lot (5\% incidence) by hot water treatment at 55 or $60^{\circ} \mathrm{C}$ for $\geq 10 \mathrm{~min}$, but could not be eradicated from two heavily infected lots $\left(>65 \%\right.$ incidence), even at $60^{\circ} \mathrm{C}$ for $40 \mathrm{~min}$. Using precisely controlled parameters, chlorine or hot water seed treatments can be used to eradicate $C$. variabile and reduce the incidence of $S$. botryosum and $V$. dahliae in spinach seed without damaging germination.
\end{abstract}

Additional keywords: Cladosporium leaf spot, seed transmission, Spinacia oleracea, Stemphylium leaf spot, Verticillium wilt

Approximately 14,000 ha of spinach (Spinacia oleracea L.) are grown in the United States annually for fresh and processed (frozen and canned) markets (5). In addition, approximately 600 to 1,600 ha of spinach seed crops are grown annually in the cool, maritime region of western Oregon and western Washington, providing $\leq 50 \%$ of the U.S. supply and $\leq 20 \%$ of the world supply of spinach seed (14). Production spinach crops in the United States are seeded at populations ranging from 0.7 to $1.5 \mathrm{million} \mathrm{seed} / \mathrm{ha}$ for processing crops, and 9.1 to 9.9 million seed/ha for baby leaf spinach crops $(21,24,27)$. Therefore, seedborne pathogens are a concern to spinach growers because of the high risk of seed transmission at such dense seeding rates.

Cladosporium variabile (Cooke) G. A. De Vries, causal agent of Cladosporium leaf spot, was considered the major leaf spot pathogen of spinach seed crops in the Pacific Northwest, where this pathogen can cause significant losses when cool and moist conditions prevail $(15,23)$. In 2001 ,

Corresponding author: L. J. du Toit

E-mail: dutoit@wsu.edu

Accepted for publication 15 July 2005 .

DOI: 10.1094/PD-89-1305

(C) 2005 The American Phytopathological Society du Toit and Derie (6) demonstrated that Stemphylium leaf spot, caused by Stemphylium botryosum Wallr., also causes a leaf spot in spinach seed crops in the Pacific Northwest. du Toit and Derie (7) also demonstrated that severity of Stemphylium and Cladosporium leaf spots is greater in the presence of spinach pollen, and that enhancement of disease in the presence of pollen is significantly greater for $S$. botryosum than $C$. variabile. The two pathogens can reduce seed quality $(9,10)$ and yield (11). In addition, spinach leaf spots can reduce the quality of processing crops and may necessitate additional hand sorting for fresh-market crops $(13,15,25)$.

Fuentes-Davila (15) reported C. variabile to be seedborne in spinach. Hernandez-Perez and du Toit (20; unpublished) detected $C$. variabile and $S$. botryosum in 48 and $100 \%$, respectively, of 77 spinach seed lots produced in Denmark, the Netherlands, New Zealand, or the United States in 2000 to 2003. Although anecdotal evidence of seed transmission of $C$. variabile in spinach was reported in Denmark in 1952 (16), Fuentes-Davila (15) could not demonstrate seed transmission of $C$. variabile in greenhouse or growth chamber trials. Hernandez-Perez (18) recently demonstrated seed transmission of $C$. variabile and $S$. botryosum in greenhouse trials. Although seed transmission has not been proven under field conditions, Raid (31) indicated that the nature of outbreaks of Stemphylium leaf spot in baby leaf spinach crops in Florida suggested that infected seed may have been the source of inoculum. The prevalence of $S$. botryosum in spinach seed lots, combined with routine interstate and international distribution of spinach seed, might account for the recent first reports or observations of this pathogen in Arizona (unpublished), California (25), Florida (32), Maryland and Delaware (13), Oregon (M. L. Putnam and L. J. du Toit, unpublished data), and Washington (6).

Verticillium wilt has not been reported in fresh-market or processing spinach crops in the United States, even when spinach seed was planted into soils heavily infested with $V$. dahliae from previous crops $(5,12)$. This may be explained by the fact that symptoms of Verticillium wilt on spinach appear to develop only after initiation of bolting (conversion from vegetative to reproductive growth; 12). Although Verticillium wilt has no economic impact on fresh-market or processing spinach crops, $V$. dahliae has been demonstrated to be prevalent in commercial seed lots and is highly systemic and readily seed transmitted in spinach $(12,37,38)$. Therefore, $V$. dahliae is a concern to the spinach industry because of the risk of introducing the pathogen into fields from infested spinach seed, resulting in infection of subsequent crops susceptible to Verticillium wilt that may be grown in rotation with spinach (38). In addition, phytosanitary certification restrictions affect export of $V$. dahliaeinfested spinach seed to some export markets (3).

Hot water and chlorine seed treatments have been reported to eradicate or significantly reduce the incidence of a number of seedborne fungi, without adversely affecting seed quality when carried out using precise treatment parameters $(4,17,26,28-$ $30,35,36)$. In a preliminary study, du Toit and Derie (8) demonstrated that the incidence of $S$. botryosum in a spinach seed lot was reduced from 54.8 to $23.3 \%$ when the seed was soaked in $1.2 \% \mathrm{NaOCl}$ for 10 $\mathrm{min}$, and to $<20 \%$ for seed soaked in chlorine for 20, 30, or $40 \mathrm{~min}$. In contrast, the incidence of $C$. variabile was reduced from 49.0 to $0.3 \%$ after chlorine treatment for $10 \mathrm{~min}$, and was not detected in seed treated with chlorine for longer durations. To our knowledge, there are no other reports on the efficacy of hot water or chlo- 
rine for treatment of spinach seed. Although some seed companies currently utilize hot water, chlorine, or both for spinach seed (M. Lyons, Alf Christianson Seed Co., personal communication), the details of these seed treatment protocols are proprietary. Therefore, the objectives of this study were to determine (i) the efficacy of hot water seed treatments and chlorine seed treatments for eradication of $C$. variabile, $S$. botryosum, and $V$. dahliae from spinach seed and (ii) the effects of these seed treatments on germination of spinach seed. In addition, because the presence of nonpathogenic fungi on spinach seed may contribute to deterioration of the seed in storage (2), hot water and chlorine seed treatments were evaluated for their potential to clean seed lots infested with nonpathogenic fungi. Preliminary results have been presented (19).

\section{MATERIALS AND METHODS}

Chlorine seed treatments. To determine efficacy of chlorine seed treatments for eradication of C. variabile, S. botryosum, and $V$. dahliae from spinach seed, four replications of five durations of seed treatment $(0,10,20,30$, and $40 \mathrm{~min})$ in $1.2 \% \mathrm{NaOCl}$ were evaluated in fall 2004 using a randomized complete block (RCB) design. Spinach seed lot 03-409 used in this trial was harvested from a hybrid seed crop trial carried out at the Washington State University-Northwestern Washington Research \& Extension Center (WSUNWREC) in Mount Vernon, WA in 2003 (9). In October 2003, using the surfacesterilized freeze-blotter seed health assay described by du Toit et al. (12), the seed lot was demonstrated to be infected with $C$. variabile, $S$. botryosum, and $V$. dahliae (9). The seed lot was stored at $18 \pm 3^{\circ} \mathrm{C}$ and 60 $\pm 10 \%$ relative humidity.

For each replication of each treatment, a mesh tea strainer containing 220 seed was immersed in $100 \mathrm{ml}$ of $1.2 \% \mathrm{NaOCl}$ in a $250-\mathrm{ml}$ glass beaker. The mouth of the beaker was covered with Parafilm (Pechiney Plastic Packaging, Menasha, WI) and the beaker was placed on an orbital shaker at $220 \mathrm{rpm}$ for the appropriate duration at ambient temperature $\left(24 \pm 3^{\circ} \mathrm{C}\right)$. The seed then were immediately triple-rinsed in the tea strainer using sterile deionized water, dried on sterile paper towel in a laminar flow hood for at least an hour, and placed in a sterile petri plate. For the control treatment $(0 \mathrm{~min})$ of each replication, 220 seed were triple-rinsed in sterile deionized water and dried. Each plate was sealed with Parafilm and stored in the dark at ambient temperature $\left(24 \pm 3^{\circ} \mathrm{C}\right)$. The seed were stored for up to 4 weeks, with increasing duration of storage from the first to the fourth replications because of limited incubator space for completing seed health assays.

For each replication of each treatment, 100 treated seed were subjected to the freeze-blotter seed health assay following the method described by du Toit et al. (12), without surface sterilization. In summary, 20 seed were plated onto a sterile germination blotter moistened with sterile deionized water in each of five 10-cm-diameter petri dishes. Each dish was sealed with Parafilm. The seed were incubated in the dark at $24^{\circ} \mathrm{C}$ for $24 \mathrm{~h}$ to imbibe, frozen at $-20^{\circ} \mathrm{C}$ for $24 \mathrm{~h}$ to prevent further germination, and placed in an incubator (Model I30BLL; Percival Scientific, Perry, IA) set at $24^{\circ} \mathrm{C}$ for 12 to 14 days with a 12 -h daynight cycle, with cool white fluorescent light and near-ultraviolet light by day. Approximately 4 to 5,8 to 9 , and 13 to 15 days after plating, the seed were examined microscopically $(\times 8$ to $\times 100$ magnification) for development of Alternaria spp., C. variabile, other Cladosporium spp., Fusarium spp., S. botryosum, and V. dahliae as described by du Toit et al. (12) and Hernandez-Perez and du Toit (unpublished).

An additional 100 seed from each replication of each treatment were subjected to a germination seed assay based on the Association of Official Seed Analysts (AOSA) protocol (39). Fifty seed were placed onto each of two double layers of Anchor seed germination blotters (38\# regular weight; Anchor Paper Co., St. Paul, $\mathrm{MN})$, moistened with deionized water, and placed over a single sheet of wax paper. The seed on each blotter were covered with an additional moistened blotter. The blotters were rolled and stored upright in a plastic bag in a seed germinator (Stults Scientific Engineering Corp., Springfield, IL) at $15^{\circ} \mathrm{C}$ with no light. Counts of germinated, abnormal, and rotten seed were carried out 4, 7, and 14 days later, following the criteria described by Yaklich (39).

The chlorine seed treatment trial was repeated 5 weeks later using seed lot 03-409. For the second trial, 50- and 60-min treatment durations in $1.2 \% \mathrm{NaOCl}$ were added, for a total of seven durations of seed treatment arranged in an RCB design with four replications.

Hot water seed treatments. To determine the effect of hot water treatment on eradication of $C$. variabile, $S$. botryosum, and $V$. dahliae from spinach seed, a splitplot RCB design with four replications was established. Water temperature (40, 45, 50, 55 , and $60^{\circ} \mathrm{C}$ ) was the whole-plot factor, and duration of treatment $(10,20,30$, and $40 \mathrm{~min}$ ) at each temperature served as the subplot factor. For each replication of each hot water temperature, four mesh tea strainers, each containing 220 spinach seed of lot 03-409, were immersed in circulating deionized water heated to the appropriate temperature in a programmable water bath (Model 1203; Fisher Scientific International, Inc., Hampton, NH). After each duration of treatment, one tea strainer was removed from the bath and immediately rinsed in running deionized water for 5 min at ambient temperature. The seed were dried and stored for 2 to 5 days. The procedure was repeated at each temperature. The water bath was emptied between temperature treatments, disinfested with $70 \%$ ethyl alcohol, triple-rinsed with deionized water, and dried. For the control treatment (0 min) of each replication, 220 seed were rinsed for $5 \mathrm{~min}$ in deionized water, dried, and stored. Freeze-blotter seed health assays and germination assays were performed as described for the chlorine seed treatments.

The hot water seed treatment trial was completed two more times. The incidence of $S$. botryosum in seed lot 03-409 dropped almost fourfold during the 4 months between completion of the second chlorine trial and the first hot water trial. Therefore, seed lots 04-305 and 04-407, harvested from a spinach seed crop fungicide trial carried out at the WSU-NWREC in 2004 (10), were used in the second and third hot water trials, respectively. Freeze-blotter seed health assays demonstrated previously that lots 04-305 and 04-407 were infected with $C$. variabile, S. botryosum, and $V$. dahliae $(10,12)$.

Data analyses. Using PROC GLM of SAS (version 8.2; SAS Institute, Cary, $\mathrm{NC}$ ), analysis of variance, means comparisons using Fisher's protected least significance difference (LSD; $P<0.05$ ) or Friedman's nonparametric rank test, correlation coefficients, and polynomial regression analysis (34) were calculated for the dependent variables measured in the seed health and germination assays. To generate homogeneous variances and normal residuals for parametric analyses of results for the chlorine trials (34), each dependent variable was calculated as a percentage of the control treatment of each replication. In addition, incidence (percent) of $S$. botryosum and incidence of Fusarium spp. detected in trial 2 were subjected to square root transformation to generate homogeneous variances. Friedman's nonparametric rank test was used to compare means for the incidences of $C$. variabile and Fusarium $\mathrm{spp}$. detected in trial 1 , and the incidence of $C$. variabile and seed germination after 7 days in trial 2, because transformations did not generate homogeneous variances or normal residuals (34).

For the hot water trials, each dependent variable was analyzed using Friedman's nonparametric rank test because of nonnormal data, except for the following variables: abnormal germination, rotten seed, and incidence of other Cladosporium spp. detected in trial 1 , and total germination in trial 2. Each variable was calculated as a percentage of the control treatment within each replication, as described above, and the following transformations were used to generate homogeneous variances or normal residuals: square root transformation for percent rotten seed in trial 1 and percent total germination in trial 2 , and arcsin 
transformation for the incidence of other Cladosporium spp. detected in trial 1.

\section{RESULTS}

Chlorine seed treatments. Treatment of spinach seed with $1.2 \% \mathrm{NaOCl}$ did not have a significant effect on seed quality in either of the chlorine trials, whether measured as percent germinated, abnormal, or rotten seed (Table 1; Fig. 1A and B). However, chlorine seed treatment significantly reduced the incidence of $C$. variabile detected in both trials (Table 1), regardless of the duration of treatment (Fig. 1C and 1D). In trial 1 , the incidence of $C$. variabile was reduced from $34.5 \%$ for nontreated seed to $\leq 1.0 \%$ for seed treated in $1.2 \% \mathrm{NaOCl}$ for $10,20,30$, or 40 min (Fig. 1C). Similarly, in trial 2, the incidence of $C$. variabile was reduced from $28.3 \%$ for nontreated seed to $\leq 0.5 \%$ for seed treated with chlorine (Fig. 1D). There was no significant difference in incidence of $C$. variabile on seed treated with $1.2 \% \mathrm{NaOCl}$ for $10,20,30,40,50$, or $60 \mathrm{~min}$ (Fig. 1D). The relationship between percent $C$. variabile detected on the seed $(Y)$ and duration of seed treatment in $1.2 \% \mathrm{NaOCl}(X)$ was best described by the following polynomial regressions: $Y=$ $34.50-6.73 X+0.45 X^{2}-0.10 X^{3}\left(R^{2}=\right.$ 0.97 , coefficient of variation $[\mathrm{CV}]=$ $38.58 \%$ ) for trial 1 , and $Y=27.86-4.50 X$ $+0.23 X^{2}\left(R^{2}=0.81, \mathrm{CV}=121.58 \%\right)$ for trial 2.

The mean incidence of $S$. botryosum was reduced from $16.8 \%$ for nontreated seed to $9.5 \%$ for seed treated with chlorine for $10 \mathrm{~min}$, and to $<7.0 \%$ for seed treated with chlorine for 20,30 , or $40 \mathrm{~min}$ in trial 1 (Fig. 1C). However, there was no significant difference in incidence of $S$. botryosum detected on seed treated with chlorine for 10, 20, 30, or $40 \mathrm{~min}$ in this trial (Table 1; Fig. 1C). In trial 2, carried out 5 weeks later, the mean incidence of $S$. botryosum had dropped to $7.8 \%$ for nontreated seed of lot 03-409, which was not significantly different from the incidence of $S$. botryosum detected on seed treated with chlorine, regardless of the duration of treatment (Fig. 1D). The relationship between percent $S$. botryosum observed on the seed $(Y)$ and duration of seed treatment in $1.2 \%$ $\mathrm{NaOCl}(X)$ was best shown by the following regressions: $Y=15.06-0.69 X+$

Trial 1
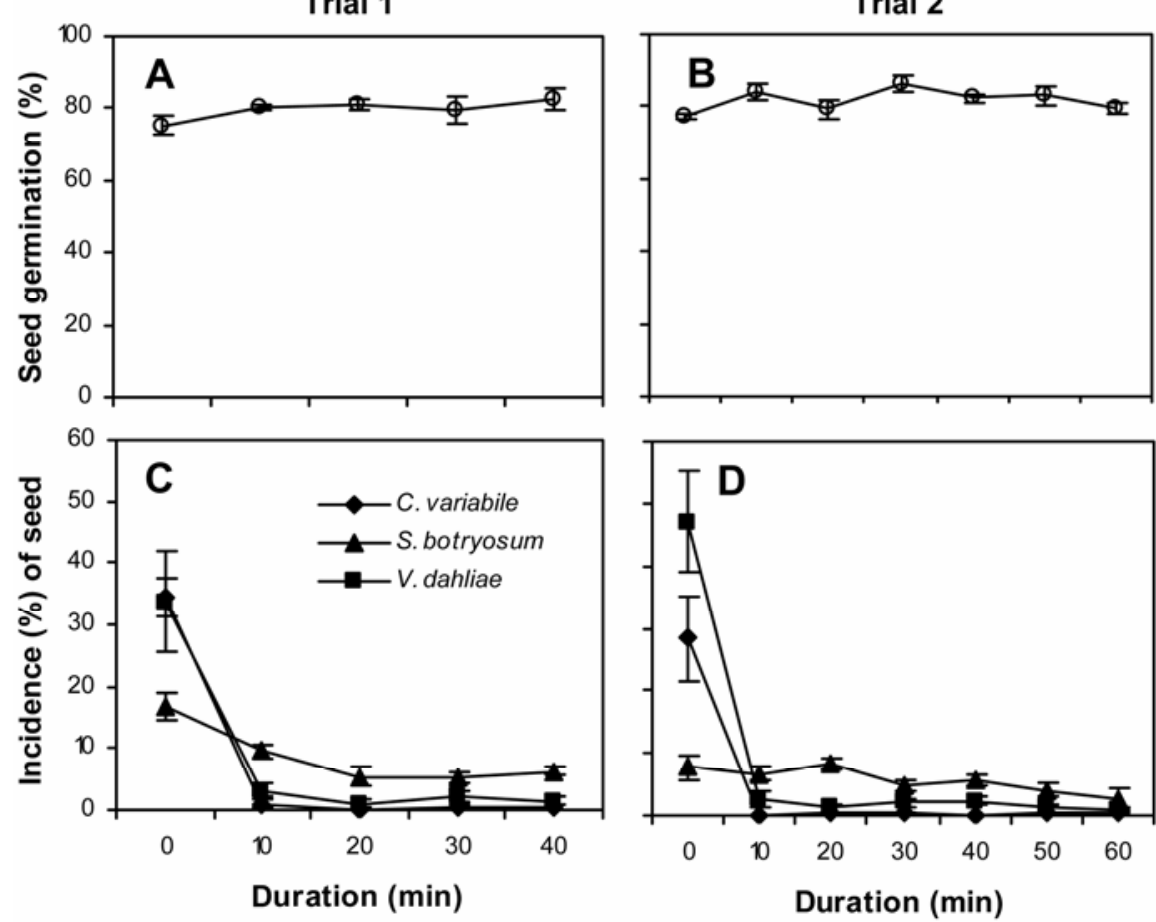

Fig. 1. Efficacy of $0,10,20,30$, and $40 \mathrm{~min}$ of chlorine $(1.2 \% \mathrm{NaOCl})$ seed treatment on germination of spinach seed (A and B) and eradication of Cladosporium variabile, Stemphylium botryosum, and Verticillium dahliae from the seed $(\mathbf{C}$ and $\mathbf{D})$ in each of two trials ( $\mathrm{A}$ and $\mathrm{C}=$ trial $1, \mathrm{~B}$ and $\mathrm{D}=$ trial 2). Each data point is the mean of four replications in a randomized complete block design, and each bar is the standard error of the mean.

Table 1. Analyses of variance for germination and seed health assays of spinach seed treated with chlorine (1.2\% $\mathrm{NaOCl})$ for durations ranging from 0 to 40 $\min (\operatorname{trial} 1)$ or $60 \min (\operatorname{trial} 2)^{\mathrm{a}}$

\begin{tabular}{|c|c|c|c|c|c|c|c|c|}
\hline \multirow[b]{3}{*}{ Dependent variable $(\%)^{\text {b }}$} & \multicolumn{4}{|c|}{ Trial 1} & \multicolumn{4}{|c|}{ Trial 2} \\
\hline & \multirow[b]{2}{*}{$\boldsymbol{R}^{2}$} & \multirow[b]{2}{*}{ CV (\%) } & \multicolumn{2}{|c|}{ MS Prob $>F$} & \multirow[b]{2}{*}{$R^{2}$} & \multirow[b]{2}{*}{$\mathrm{CV}(\%)$} & \multicolumn{2}{|c|}{ MS Prob $>F$} \\
\hline & & & Replication & Duration & & & Replication & Duration \\
\hline \multicolumn{9}{|l|}{ Germination assay } \\
\hline Germination at 4 days & 0.359 & -67.56 & 0.7512 & 0.3416 & 0.610 & -102.13 & 0.0040 & 0.7450 \\
\hline Germination at 7 days & 0.385 & -81.72 & 0.5167 & 0.4114 & 0.140 & 57.58 & 1.0000 & 0.8100 \\
\hline Total germination & 0.722 & -84.30 & 0.0081 & 0.8270 & 0.446 & -89.03 & 0.3300 & 0.2020 \\
\hline Abnormal germination & 0.538 & -196.19 & 0.1613 & 0.3248 & 0.748 & -148.52 & 0.0002 & 0.3260 \\
\hline Rotten seed & 0.690 & $-2,293.19$ & 0.0327 & 0.1702 & 0.611 & -227.54 & 0.0058 & 0.4653 \\
\hline \multicolumn{9}{|c|}{ Seed health assay (seed infected) } \\
\hline Cladosporium variabile & 0.671 & 32.63 & 1.0000 & 0.0063 & 0.632 & 2.04 & 1.0000 & 0.0030 \\
\hline Stemphylium botryosum & 0.675 & 26.34 & 0.0557 & 0.1215 & 0.603 & 11.11 & 0.0129 & 0.0941 \\
\hline Verticillium spp. & 0.635 & 4.07 & 0.0805 & 0.1700 & 0.295 & 2.96 & 0.6640 & 0.4960 \\
\hline Other Cladosporium spp. & 0.694 & 3.09 & 0.1233 & 0.0390 & 0.696 & 4.50 & 0.0010 & 0.2910 \\
\hline Fusarium spp. & 0.843 & 19.84 & 1.0000 & $<0.0001$ & 0.454 & 36.44 & 0.0700 & 0.5890 \\
\hline Alternaria spp. & 0.579 & 15.42 & 0.4666 & 0.0760 & 0.467 & 14.52 & 0.1270 & 0.3180 \\
\hline
\end{tabular}

${ }^{a}$ Each trial consisted of a randomized complete block design with four replications of each duration of treatment in $1.2 \% \mathrm{NaOCl}$, as described in the text; MS Prob = mean square probability, $R^{2}=$ coefficient of determination, and CV = coefficient of variation.

${ }^{\mathrm{b}}$ For each replication of each treatment, 100 seed were subjected to a blotter germination assay (39) and 100 seed were subjected to a freeze-blotter seed health assay (12). To facilitate parametric statistical analyses, the dependent variable was calculated as a percentage of the control treatment. Results for $S$. botryosum and Fusarium spp. in trial 2 were square root transformed to generate homogeneous variances. Friedman's nonparametric analyses were used for $C$. variabile and Fusarium spp. in trial 1, and C. variabile and germination at 7 days in trial 2, because transformations did not generate homogeneous variances. 
treatment in either trial (Table 1; Fig. 1C and D). The relationship between percent $V$. dahliae observed on the seed $(Y)$ and duration of seed treatment in $1.2 \% \mathrm{NaOCl}$ $(X)$ was best described by the following regressions: $Y=33.47-4.62 X+0.20 X^{2}$ $\left(R^{2}=0.95, \mathrm{CV}=39.09 \%\right)$ for trial 1 , and $Y$ $=46.53-7.10 X+0.36 X^{2}+0.01 X^{3}\left(R^{2}=\right.$ $0.88, \mathrm{CV}=76.90 \%$ ) for trial 2 .

The mean incidence of Cladosporium spp. other than $C$. variabile observed on the spinach seed was reduced significantly in both trials as a result of chlorine treatment, from $76.5 \%$ for nontreated seed to $<11.0 \%$ in trial 1 , and from 44.8 to $<7.0 \%$ in trial 2 (data not shown). Significant differences among the durations of chlorine treatment were detected only in trial 1 (Table 1), in which the incidence of other Cladosporium spp. decreased incrementally from 10.3 to $5.3 \%$ with increasing duration of chlorine treatment from 10 to
40 min (data not shown). Similar results were observed for the mean incidence of Fusarium spp. detected in each trial (Table 1), although a low incidence of Fusarium spp. was present in the nontreated seed in each trial (mean of 3.0 and $1.3 \%$ in trials 1 and 2 , respectively). The mean incidence of Alternaria spp. observed on the seed was significantly lower for all durations of chlorine seed treatment compared with the control treatment $(58.8$ and $57.3 \%$ in trials 1 and 2, respectively; data not shown). However, in both trials, there were no significant differences in the mean incidence of Alternaria spp. among the durations of chlorine treatment (Table 1). In the first chlorine trial, a significant correlation was detected between percent rotten seed in the germination assay and percentage of each of the following fungi enumerated in the seed health assay: $r=0.49$ at $P=0.0497$ for $V$. dahliae, $r=0.53$ at $P=0.0344$ for other Cladosporium spp., and $r=0.63$ at $P$ $=0.0095$ for Fusarium spp.

Hot water seed treatments. For each of the variables measured in the seed germination assays following hot water seed treatment, a significant $(0.01<P \leq 0.05)$ or highly significant $(P \leq 0.01)$ interaction was detected between the hot water temperatures and the duration of treatment, except for percent rotten seed in trial 1 (Table 2). Of the four dependent variables analyzed using parametric analyses for the hot water trials (Table 2), the whole-plot factor of temperature was significant for three variables: percent abnormal germination and percent other Cladosporium spp. detected in trial 1 , and percent total germination in trial 2. The subplot factor of duration of treatment was significant for percent other Cladosporium spp. detected in trial 1 and percent total germination in trial 2.

Table 2. Analyses of variance for germination and seed health assays of spinach seed treated with hot water ${ }^{\mathrm{a}}$

\begin{tabular}{|c|c|c|c|c|c|c|c|}
\hline \multirow[b]{2}{*}{ Trial, assay, and dependent variable $(\%)^{\text {b }}$} & \multirow[b]{2}{*}{$R^{2}$} & \multirow[b]{2}{*}{ CV $(\%)$} & \multicolumn{5}{|c|}{ Mean square probability $>\boldsymbol{F}$} \\
\hline & & & Temp & Rep & Rep-Temp & Dur & Temp-Dur \\
\hline \multicolumn{8}{|l|}{ Trial 1} \\
\hline \multicolumn{8}{|l|}{ Germination assay } \\
\hline Germination at 4 days & 0.80 & 27.56 & - & 1.0000 & - & - & $<0.0001$ \\
\hline Total germination & 0.77 & 30.54 & - & 1.0000 & - & - & $<0.0001$ \\
\hline Abnormal germination & 0.82 & 311.60 & 0.0492 & $<0.0001$ & 0.1314 & 0.4530 & $<0.0001$ \\
\hline Rotten seed & 0.80 & 13.46 & 0.1761 & $<0.0001$ & 0.1724 & 0.4321 & 0.7500 \\
\hline \multicolumn{8}{|l|}{ Seed health assay } \\
\hline Stemphylium botryosum & 0.57 & 37.57 & - & 1.0000 & - & - & $<0.0001$ \\
\hline Cladosporium variabile & 0.82 & 246.14 & - & 0.3992 & - & - & $<0.0001$ \\
\hline V. dahliae & 0.94 & 13.38 & - & 1.0000 & - & - & $<0.0001$ \\
\hline Other Cladosporium spp. & 0.69 & 5.89 & 0.0143 & $<0.0001$ & 0.1001 & 0.0026 & 0.0009 \\
\hline Fusarium spp. & 0.70 & 28.21 & - & 1.0000 & - & - & $<0.0001$ \\
\hline Alternaria spp. & 0.88 & 21.80 & - & 1.0000 & - & - & $<0.0001$ \\
\hline \multicolumn{8}{|l|}{ Trial 2} \\
\hline \multicolumn{8}{|l|}{ Germination assay } \\
\hline Germination at 4 days & 0.85 & 25.10 & - & 1.0000 & - & - & $<0.0001$ \\
\hline Total germination & 0.89 & 14.81 & $<0.0001$ & $<0.0001$ & 0.1831 & $<0.0001$ & 0.0200 \\
\hline Abnormal germination & 0.71 & 35.02 & - & 1.0000 & - & - & $<0.0001$ \\
\hline Rotten seed & 0.37 & 5.53 & - & 1.0000 & - & - & $<0.0001$ \\
\hline \multicolumn{8}{|l|}{ Seed health assay } \\
\hline S. botryosum & 0.91 & 37.57 & - & 1.0000 & - & - & $<0.0001$ \\
\hline C. variabile & 0.61 & 14.60 & - & 1.0000 & - & - & $<0.0001$ \\
\hline V. dahliae & 0.91 & 18.43 & - & 1.0000 & - & - & $<0.0001$ \\
\hline Other Cladosporium spp. & 0.63 & 36.41 & - & 1.0000 & - & - & $<0.0001$ \\
\hline Fusarium spp. & 0.96 & 13.45 & - & 1.0000 & - & - & $<0.0001$ \\
\hline Alternaria spp. & 0.96 & 12.32 & - & 1.0000 & - & - & $<0.0001$ \\
\hline \multicolumn{8}{|l|}{ Trial 3} \\
\hline \multicolumn{8}{|l|}{ Germination assay } \\
\hline Germination at 4 days & 0.83 & 26.47 & - & 1.0000 & - & - & $<0.0001$ \\
\hline Total germination & 0.77 & 31.25 & - & 1.0000 & - & - & $<0.0001$ \\
\hline Abnormal germination & 0.56 & 42.92 & - & 1.0000 & - & - & $<0.0001$ \\
\hline Rotten seed & 0.24 & 56.42 & - & 1.0000 & - & - & $<0.0001$ \\
\hline \multicolumn{8}{|l|}{ Seed health assay } \\
\hline S. botryosum & 0.90 & 20.63 & - & 1.0000 & - & - & $<0.0001$ \\
\hline C. variabile & 0.75 & 10.41 & - & 1.0000 & - & - & $<0.0001$ \\
\hline V. dahliae & 0.90 & 19.79 & - & 1.0000 & - & - & $<0.0001$ \\
\hline Other Cladosporium spp. & 0.66 & 32.89 & - & 1.0000 & - & - & $<0.0001$ \\
\hline Fusarium spp. & 0.97 & 11.76 & - & 1.0000 & - & - & $<0.0001$ \\
\hline Alternaria spp. & 0.95 & 14.05 & - & 1.0000 & - & - & $<0.0001$ \\
\hline
\end{tabular}

${ }^{\text {a }}$ Each trial consisted of a split-plot randomized complete block design with four replications. Temp $=$ water temperatures of $40,45,50,55$, or $60^{\circ} \mathrm{C}$ (whole plots); Rep = replication; Dur = durations of $0,10,20,30$, or 40 min of treatment (subplots); $R^{2}=$ coefficient of determination, and CV $=$ coefficient of variation.

b Seed lots 03-409, 04-305, and 04-407 were used in trials 1, 2, and 3, respectively. For each replication of each treatment combination, 100 seed were subjected to a blotter germination assay (39), and 100 seed were subjected to a freeze-blotter seed health assay (12). Except for abnormal germination, rotten seed, and other Cladosporium spp. in trial 1, and total germination in trial 2, dependent variables were analyzed using Friedman's nonparametric rank test because of nonnormal data. Variables subjected to parametric analyses were calculated as a percentage of the control treatment. Square root transformations were used for rotten seed in trial 1 and total germination in trial 2, and arcsin transformation for other Cladosporium spp. in trial 1. 
In trial 1 , seed germination after 4 days was significantly lower for seed treated at $50^{\circ} \mathrm{C}$ for $40 \mathrm{~min}, 55^{\circ} \mathrm{C}$ for $\geq 20 \mathrm{~min}$, or $60^{\circ} \mathrm{C}$ for any duration compared with nontreated seed (data not shown). Total germination measured after 14 days was significantly lower than that of the nontreated seed (mean of $80.3 \%$ ) for seed treated at $55^{\circ} \mathrm{C}$ for 30 or 40 min or at $60^{\circ} \mathrm{C}$ for any duration, but not for seed treated at 40,45 , or $50^{\circ} \mathrm{C}$ for up to $40 \mathrm{~min}$ (Fig. 2A). Germination was prevented completely when the seed was soaked at $60^{\circ} \mathrm{C}$ for 30 or $40 \mathrm{~min}$ (Fig. 2A). Germination of nontreated seed was much lower for seed lots 04-305 (48.0\%) and 04-407 $(40.8 \%)$ used in trials 2 and 3 , respectively, compared with lot 03-409 (80.3\%) used in trial 1 (Fig. 2A, B, and C). In trials 2 and 3 , seed germination after 4 days was reduced significantly by treatment at $50^{\circ} \mathrm{C}$ for only $20 \mathrm{~min}$ compared with $40 \mathrm{~min}$ in trial 1 , and at all durations of treatment at 55 and $60^{\circ} \mathrm{C}$ (data not shown). Results similar to those of trial 1 were observed for total germination measured in hot water trials 2 and 3 (Fig. $2 \mathrm{~B}$ and $\mathrm{C}$, respectively), except that germination also was reduced significantly by treatment in $55^{\circ} \mathrm{C}$ water for $\geq 20 \mathrm{~min}$ in trial 2 and $\geq 10$ min in trial 3 , and at $50^{\circ} \mathrm{C}$ for $\geq 30 \mathrm{~min}$ in trial 3 .

In hot water trial 1 , the percent rotten seed observed in the germination assay was not affected significantly by any of the hot water treatments when compared with the nontreated seed (mean of $0.8 \%$; data not shown). The percent abnormal seed was reduced significantly from $3.5 \%$ for nontreated seed to $0.0 \%$ for seed treated at $60^{\circ} \mathrm{C}$ for 30 to $40 \mathrm{~min}$ in trial 1 , because none of the seed germinated following these treatments. Similar results for percent rotten seed and abnormal seed were detected in trials 2 and 3 , except that the
Trial 1
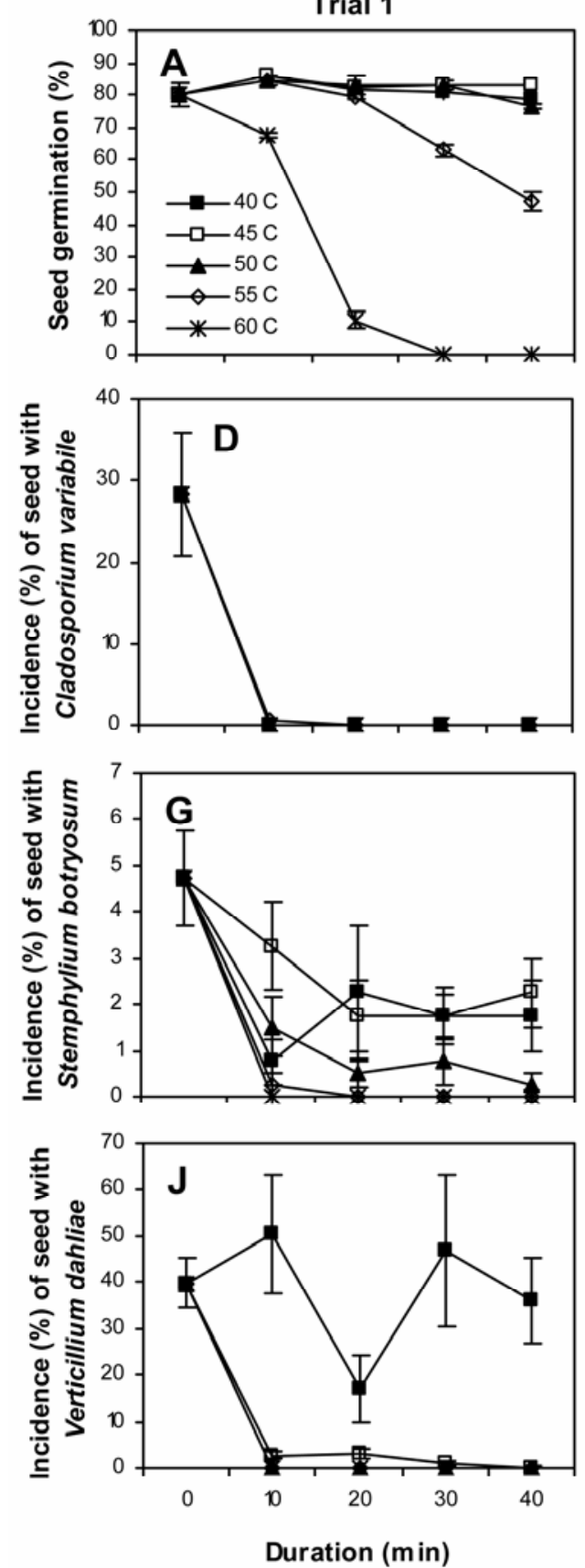

Trial 2
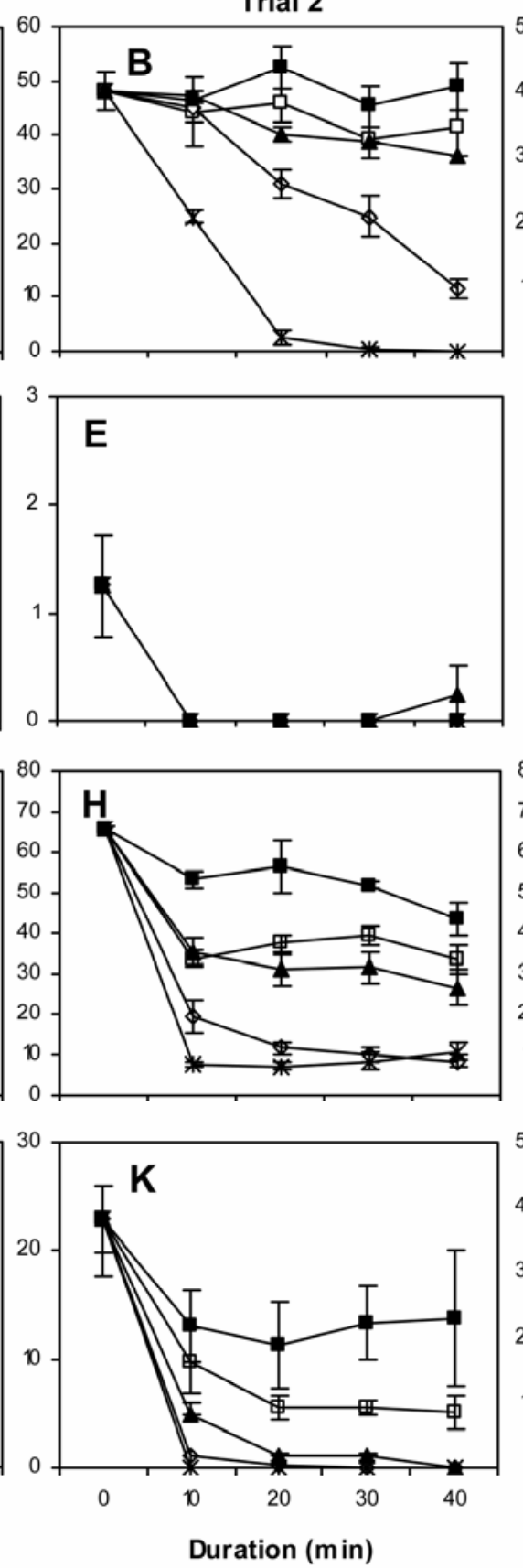

Trial 3
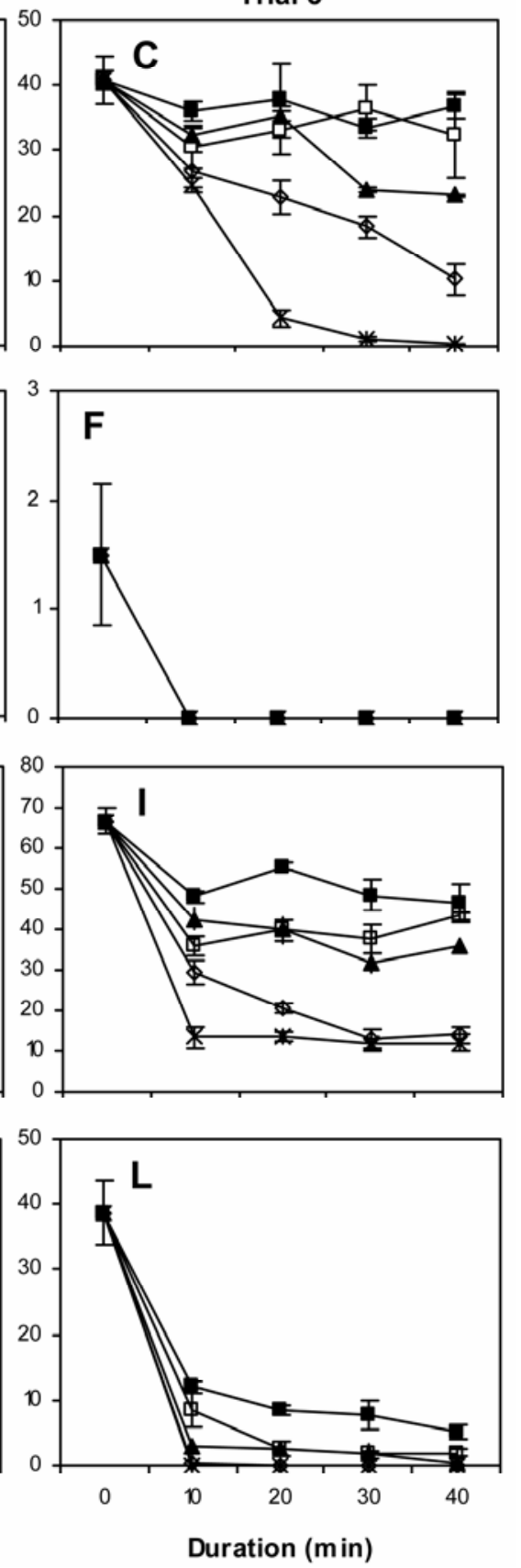

Fig. 2. Efficacy of 0, 10, 20,30, and $40 \mathrm{~min}$ of hot-water treatment at 40,45, 50, 55, and $60^{\circ} \mathrm{C}$ on germination of spinach seed (A to C) and eradication of Cladosporium variabile (D to F), Stemphylium botryosum ( $\mathbf{G}$ to $\mathbf{I})$, and Verticillium dahliae (J to $\mathbf{L})$ from the seed. Seed lot 03-409 was used in trial 1 (A, D, $\mathrm{G}$, and J), lot 04-305 was used in trial 2 (B, E, H, and K), and lot 04-407 was used in trial 3 (C, F, I, and L). Each data point is the mean of four replications in a split-plot randomized complete block design, and each bar is the standard error of the mean. 
percent rotten seed was reduced significantly for seed treated at $60^{\circ} \mathrm{C}$ for $40 \mathrm{~min}$ in trial 2 , and at $60^{\circ} \mathrm{C}$ for $\geq 20 \mathrm{~min}$ in trial 3 , because none of the seed germinated following these temperature-duration treatments (data not shown).

For each of the dependent variables recorded in the freeze-blotter seed health assays, a highly significant interaction was detected between water temperature and the duration of treatment at each temperature (Table 2). In all three trials, $C$. variabile was eradicated from the seed by all hot water treatments (Fig. 2D, E, and F), except at $50^{\circ} \mathrm{C}$ for $40 \mathrm{~min}$ in trial 2, when C. variabile was detected at an incidence of $0.3 \%$ (Fig. 2E). The mean incidence of $S$. botryosum in the nontreated seed was only $4.8 \%$ in trial 1 (Fig. 2G). Consistent and significant reductions in the mean incidence of this pathogen were detected on seed treated at $50^{\circ} \mathrm{C}$ or higher for any duration in trial 1 . In this trial, $S$. botryosum was eradicated from seed treated at $55^{\circ} \mathrm{C}$ for $\geq 20 \mathrm{~min}$ or $60^{\circ} \mathrm{C}$ for $\geq 10 \mathrm{~min}$ (Fig. 2G). In trials 2 and 3, S. botryosum was observed on 65.8 and $66.8 \%$ of the nontreated seed, respectively (Fig. $2 \mathrm{H}$ and I, respectively). In both trials, significant reductions in incidence of $S$. botryosum were detected on seed heated to $40^{\circ} \mathrm{C}$ for $40 \mathrm{~min}$, or at higher temperatures for any duration (Fig. 2H and I). However, S. botryosum was not eradicated from spinach seed in either trial, even at $60^{\circ} \mathrm{C}$ for 40 min, at which temperature and duration the incidence of $S$. botryosum was reduced to $10.8 \%$ in trial 2 (Fig. $2 \mathrm{H}$ ) and $12.0 \%$ in trial 3 (Fig. 2I). The mean incidence of $V$. dahliae in nontreated seed was 39.8, 23.0, and $38.8 \%$ in trials 1,2 , and 3, respectively (Fig. 2J, K, and L). Significant reductions in the incidence of $V$. dahliae were observed for seed treated at $\geq 45^{\circ} \mathrm{C}$ in all three trials, and at $40^{\circ} \mathrm{C}$ in trial 3 (Fig. $2 \mathrm{~L}$ ). $V$. dahliae was eradicated from spinach seed treated at $\geq 50^{\circ} \mathrm{C}$ in trial 1 (Fig. $2 \mathrm{~J}$ ) $; 50^{\circ} \mathrm{C}$ for $40 \mathrm{~min}, 55^{\circ} \mathrm{C}$ for $\geq 30 \mathrm{~min}$, or $60^{\circ} \mathrm{C}$ for any duration in trial 2 (Fig. $2 \mathrm{~K}$ ); and $55^{\circ} \mathrm{C}$ for $\geq 20 \mathrm{~min}$ or $60^{\circ} \mathrm{C}$ for any duration in trial 3 (Fig. 2L).

The relationship between incidence of seedborne $C$. variabile $(Y)$, water temperature $(X)$, and duration of treatment at that temperature $(Z)$, was best described by the following regressions: $Y=26.34-3.98 Z+$ $0.17 Z^{2}\left(R^{2}=0.76, \mathrm{CV}=76.90 \%\right)$ in trial 1 , $Y=1.16-0.17 Z+0.01 Z^{2}\left(R^{2}=0.57, \mathrm{CV}\right.$ $=319.12 \%)$ in trial 2 , and $Y=1.40-0.21 Z$ $+0.01 Z^{2}\left(R^{2}=0.59, \mathrm{CV}=370.67 \%\right)$ in trial 3. Similarly, the regressions for $S$. botryosum were: $Y=6.72-0.11 X-0.02 Z$ $\left(R^{2}=0.47, \mathrm{CV}=108.73 \%\right)$ in trial $1, Y=$ $106.15-2.10 X+4.32 Z-0.18 Z^{2}\left(R^{2}=\right.$ $0.86, \mathrm{CV}=23.77 \%$ ) in trial 2 , and $Y=$ $100.76-1.86 X+4.32 Z-0.20 Z^{2}\left(R^{2}=\right.$ $0.85, \mathrm{CV}=19.56 \%)$ in trial 3 . The bestfitting regressions for seedborne $V$. dahliae were: $Y=3329.97-190.25 X+3.60 X^{2}-$ $0.02 X^{3}\left(R^{2}=0.64, \mathrm{CV}=144.50 \%\right)$ in trial
$1, Y=34.71-0.61 X+0.26 Z-0.02 Z^{2}\left(R^{2}\right.$ $=0.65, \mathrm{CV}=87.64 \%)$ in trial 2 , and $Y=$ $71.68-2.06 X+0.01 X^{2}-0.43 Z-0.01 Z^{2}+$ $0.01 X Z\left(R^{2}=0.90, \mathrm{CV}=61.82 \%\right)$ in trial 3.

The mean incidence of Cladosporium spp. other than $C$. variabile observed on the seed was reduced significantly from that of the nontreated seed by treatment at $40^{\circ} \mathrm{C}$ for $\geq 10 \mathrm{~min}$, similar to the effects of hot water treatment on $C$. variabile (data not shown). However, a low incidence (0.3 to $2.0 \%$ ) of these other Cladosporium spp. was still detected on seed treated at $60^{\circ} \mathrm{C}$ in each trial. The mean incidence of Fusarium spp. was reduced significantly from that of the nontreated seed by hot water treatment at $\geq 45^{\circ} \mathrm{C}$ in trial 1 , and at $40^{\circ} \mathrm{C}$ for $\geq 20 \mathrm{~min}$ in trial 2 or $\geq 30 \mathrm{~min}$ in trial 3 . However, the mean incidence of Fusarium spp. on nontreated seed was low in trial 1 (2.5\%) compared with trials 2 and 3 (52.8 and $60.8 \%$, respectively; data not shown). The mean incidence of Alternaria spp. was reduced significantly by treating seed at $40^{\circ} \mathrm{C}$ for $\geq 20 \mathrm{~min}$ in trials 1 and 3 , and $\geq 30$ $\mathrm{min}$ in trial 2. Alternaria spp. were largely eradicated from seed treated at 55 or $60^{\circ} \mathrm{C}$ (data not shown).

Significant correlations were detected between the percent rotten seed and the incidence of each of the fungi observed on the seed in trial 3: $r=0.88$ at $P=0.0206$ for $C$. variabile, $r=0.94$ at $P=0.0047$ for $S$. botryosum, $r=0.95$ at $P=0.0034$ for $V$. dahliae, $r=0.91$ at $P=0.0126$ for other Cladosporium spp., $r=0.94$ at $P=0.0046$ for Fusarium spp., and $r=0.94$ at $P=$ 0.0053 for Alternaria spp.

\section{DISCUSSION}

Treatment of spinach seed in $1.2 \%$ $\mathrm{NaOCl}$ or in hot water significantly reduced the incidences of $C$. variabile, $S$. botryosum, and $V$. dahliae detected on the seed. Seed germination was not adversely affected by chlorine treatment, even after $60 \mathrm{~min}$ in $1.2 \% \mathrm{NaCOl}$. However, seed germination was adversely affected by soaking spinach seed in $50^{\circ} \mathrm{C}$ water for $\geq 30 \mathrm{~min}$, or 55 or $60^{\circ} \mathrm{C}$ water for $\geq 10 \mathrm{~min}$, demonstrating the need to control water temperature precisely during hot water seed treatments to avoid damaging spinach seed.

C. variabile and $V$. dahliae were largely eradicated from spinach seed by chlorine treatment for as little as $10 \mathrm{~min}$. In contrast, $S$. botryosum was not eradicated from spinach seed by chlorine treatment, even after $60 \mathrm{~min}$ in $1.2 \% \mathrm{NaOCl}$. There was no significant difference in the incidence of the fungus detected on seed treated with chlorine for durations ranging from 10 to $60 \mathrm{~min}$, although the incidence of seedborne $S$. botryosum was reduced by 43 to $67 \%$ of that detected on the nontreated seed. Similar results were obtained by du Toit and Derie (8) and du Toit et al. (12) for spinach seed infected with $C$. variabile
(49.0\%), S. botryosum (54.8\%), and $V$. dahliae $(8.3 \%)$. C. variabile was eradicated following 20 to $40 \mathrm{~min}$ in $1.2 \%$ $\mathrm{NaOCl}(8)$. The incidence of S. botryosum was reduced by chlorine treatment, with the greatest reduction $(67 \%$ of that on the nontreated seed) observed on seed treated for $40 \mathrm{~min}$, after which $S$. botryosum was still observed on $18 \%$ of the seed (8). Similarly, $V$. dahliae was observed in $<1.0 \%$ of the seed following chlorine treatment for 20 to $40 \mathrm{~min}$ (12).

Hot water seed treatment was very effective at eradicating $C$. variabile from spinach seed in this study. The fungus could not be detected on seed treated in $40^{\circ} \mathrm{C}$ water for only $10 \mathrm{~min}$, with no adverse effect on germination. $V$. dahliae was less sensitive to hot water treatment than C. variabile, necessitating temperatures of $\geq 50^{\circ} \mathrm{C}$ for eradication of this pathogen from the seed. Nonetheless, seed treatment at $45^{\circ} \mathrm{C}$ may be valuable for reducing the incidence of seedborne $V$. dahliae. For example, the incidence of seedborne $V$. dahliae was reduced to $<10 \%$ on seed treated at $45^{\circ} \mathrm{C}$ for $20 \mathrm{~min}$ or longer in this study, the threshold set by a phytosanitary certification requirement for export of spinach seed to Mexico (3). S. botryosum was eradicated from a spinach seed lot with a low incidence of infection $(5 \%)$, by treating the seed in $55^{\circ} \mathrm{C}$ water for $\geq 20 \mathrm{~min}$ or $60^{\circ} \mathrm{C}$ for $\geq 10 \mathrm{~min}$. However, except for the 20 min treatment at $55^{\circ} \mathrm{C}$, germination was reduced significantly by these temperature-duration combinations. Furthermore, hot water treatment did not eradicate S. botryosum from either of two heavily infected seed lots ( $>65 \%$ incidence), even at $60^{\circ} \mathrm{C}$ for $40 \mathrm{~min}$.

The relative efficacy of hot water treatments against seedborne $C$. variabile, $S$. botryosum, and $V$. dahliae may reflect the degree of internal infection of spinach seed by the pathogens. Using transmission electron microscopy, Hernandez-Perez (18) observed intracellular hyphae of $C$. variabile and $S$. botryosum in the pericarps of spinach seed. Component seed assays, in which the pericarp and embryo of each seed were separated and tested individually by freeze-blotter seed health assay, demonstrated that both $C$. variabile and $S$. botryosum can infect the pericarps and embryos of spinach seed (18). However, the component seed assays also demonstrated that infection of spinach seed by S. botryosum was more internal than that of $C$. variabile, because a higher percentage of the embryos were infected with $S$. botryosum than $C$. variabile for each of the seed lots evaluated (18). A component seed assay carried out 3 months after completion of the third hot water trial in this study showed that $S$. botryosum was present in 39 and $54 \%$ of the embryos and pericarps, respectively, of lot 04-407 (data not shown). In comparison, $C$. variabile could no longer be detected in any of the seed. 
The more deep-seated nature of infection of spinach seed by $S$. botryosum than $C$. variabile may make $C$. variabile more vulnerable than $S$. botryosum to the fungicidal effects of chlorine and heat during seed treatment.

The highly systemic nature of infection of spinach plants by $V$. dahliae suggests internal infection of spinach seed by $V$. dahliae $(12,37,38)$. This might explain the greater tolerance of $V$. dahliae to hot water seed treatment compared with $C$. variabile, but does not explain the greater tolerance of $S$. botryosum to hot water treatment compared with $V$. dahliae, or the greater sensitivity of both $C$. variabile and $V$. dahliae to chlorine seed treatment compared with S. botryosum. Van der Spek (37) provided limited evidence of infection of spinach seed by $V$. dahliae by a vascular link from the mother plants. In contrast, Snyder and Wilhem (33) reported that seedborne infection by this fungus resulted from external contamination of spinach flowers. The specific mode or modes of infection of spinach seed by $V$. dahliae may affect the degree of internal infection. Research is needed to clarify the specific locations of infection of spinach seed by $V$. dahliae (e.g., using component seed assays and electron microscopy). In addition, research on the relative heat tolerance and chlorine tolerance of $C$. variabile, S. botryosum, and $V$. dahliae may help clarify the results observed in this study.

Competitive interactions among fungi present on spinach seed after hot water or chlorine treatment may influence which fungi develop on the seed and can be detected using a dissecting microscope. In an attempt to counteract this effect when using the freeze-blotter seed health assay in this study, the seed were examined at 4 - to 5-day intervals for up to 2 weeks after plating, thereby maximizing the opportunity to detect slow-growing, lesscompetitive fungi present on the seed. Cladosporium spp. other than C. variabile were observed on the spinach seed lots evaluated in this study. These fungi displayed chlorine and hot water sensitivity similar to that of $C$. variabile, because either $10 \mathrm{~min}$ of chlorine treatment or $\geq 10$ min in water heated to $\geq 45^{\circ} \mathrm{C}$ significantly reduced the incidence of these fungi. The incidence of seedborne Fusarium spp. also was reduced significantly by chlorine treatment, as was the incidence of Alternaria spp., which proved slightly less sensitive to chlorine seed treatment than Fusarium spp. Fusarium and Alternaria spp. were mostly eradicated from spinach seed by treatment in 55 or $60^{\circ} \mathrm{C}$ water. Significant reductions in incidence of these genera also were detected by treatment in 45 or $50^{\circ} \mathrm{C}$ water, with increasing efficacy the longer the duration of treatment. Although the pathogenicity of these fungi on spinach was not evaluated in this study, their presence on the seed may contribute to deterioration of spinach seed in storage (2). Therefore, chlorine or hot water seed treatments could be used to clean seed heavily infested with such saprophytic fungi.

Results of the hot water seed treatments evaluated in this study corroborate several other studies on the efficacy of hot water for control of a number of seedborne pathogens of vegetables. Nega et al. (29) found that hot water treatment at $50^{\circ} \mathrm{C}$ for 20 to $30 \mathrm{~min}$, or at $53^{\circ} \mathrm{C}$ for 10 to $30 \mathrm{~min}$ controlled Alternaria dauci, A. radicina, A. alternata, and A. brassicicola on carrot, cabbage, celery, parsley, and lamb's lettuce seed. Aveling et al. (4) treated onion seed at $50^{\circ} \mathrm{C}$ for $20 \mathrm{~min}$ to control A. porri and $S$. vesicarium. Various studies on hot water treatment of carrot seed illustrate the importance of evaluating a range of temperatures and durations of treatment for control of different seedborne pathogens. Pryor et al. (30) demonstrated that carrot seed treated in water or $1.0 \% \mathrm{NaOCl}$ heated to $50^{\circ} \mathrm{C}$ for $20 \mathrm{~min}$ eradicated $A$. radicina with minimal reduction in germination. Strandberg (35) reduced the incidence of A. dauci by treating carrot seed in $50^{\circ} \mathrm{C}$ water for $12 \mathrm{~min}$. Strandberg and White (36) subsequently demonstrated that the duration of survival of $A$. dauci in carrot seed could be reduced more effectively by hot water treatment at $55^{\circ} \mathrm{C}$ for $20 \mathrm{~min}$, but longer durations of treatment at this temperature reduced emergence severely. Similarly, Hermansen et al. (17) showed that placing carrot seed in $54^{\circ} \mathrm{C}$ water for 20 min eradicated $A$. dauci without affecting germination, emergence, or yield adversely.

Based on the results of this study, if a spinach seed lot infected with C. variabile, $S$. botryosum, and Verticillium spp. is treated in $1.2 \% \mathrm{NaOCl}$ for $\geq 20 \mathrm{~min}, C$. variabile and $V$. dahliae probably will be eradicated from the seed, and the incidence of $S$. botryosum may be reduced significantly with no adverse effect on seed germination. Results of the hot water seed treatment trials suggest that a spinach seed lot infested with $C$. variabile, $S$. botryosum, and $V$. dahliae could be treated in $50^{\circ} \mathrm{C}$ water for $20 \mathrm{~min}$ to eradicate $C$. variabile, reduce the incidence of $S$. botryosum and $V$. dahliae, and largely eradicate Fusarium, Alternaria, and other Cladosporium spp. with no adverse effect on seed germination. Research is needed to determine the effect of hot water or chlorine seed treatments on other important seedborne pathogens of spinach (e.g., Cucumber mosaic virus [40] and Peronospora farinosa f. sp. spinaciae [22]). In addition, specific temperatures and durations of hot water treatment need to be evaluated on a broader range of spinach cultivars to determine the optimum conditions necessary to avoid injuring the seed while maximizing control of seedborne pathogens. The three seed lots evaluated in this study differed slightly in response to hot water treatments, with reduction in germination observed at lower temperatures and shorter durations of hot water treatment for the two seed lots with poor seed germination. Similarly, Strandberg and White (36) observed differential responses in seed performance of 25 carrot cultivars subjected to hot water seed treatment. They suggested that different seed lots of the same cultivar may differ in seed performance following hot water seed treatment. Similarly, Hermansen et al. (17) reported that small carrot seed were more sensitive to hot water than larger seed. Strandberg and White (36) demonstrated that emergence from hot water-treated carrot seed was reduced following 6 weeks of seed storage at 70 to $80 \%$ relative humidity, but not at 20 to $60 \%$ relative humidity. Therefore, research is needed to determine the longterm effects of hot water and chlorine seed treatments on shelf-life of spinach seed.

Hot water seed treatments could be used in conventional and organic spinach production. Although seed treatment with chlorine or hot water did not eradicate $S$. botryosum from spinach seed without affecting germination, it may be possible to combine chlorine or hot water seed treatments with fungicide or biological seed treatments to eradicate the pathogen or prevent seed transmission. Research is needed to evaluate the efficacy of hot chlorine solutions and other methods of seed treatment (e.g., hot air, aerated steam, and radiation; 1,26,30) on seedborne pathogens of spinach, particularly recalcitrant internal infections by pathogens such as S. botryosum.

\section{ACKNOWLEDGMENTS}

We gratefully acknowledge financial support for this project from the Robert MacDonald Vegetable Seed Memorial Fund, the Puget Sound Seed Growers' Association, the Washington State Commission for Pesticide Registration, and the Alfred Christianson Family Endowment; seed samples provided by seed companies; and technical assistance from M. Derie, K. Baber, L. Brissey, K. Brooks, B. Case, B. Holmes, N. Lloyd, and A. Morrison. This project was supported by the Agricultural Research Center of the College of Agricultural, Human, and Natural Resource Sciences at Washington State University, and is listed as Plant Pathology New Series No. 0404.

\section{LITERATURE CITED}

1. Agarwal, V. K., and Sinclair, J. B. 1997. Control of seedborne pathogens. Pages 410-510 in Principles of Seed Pathology, 2nd ed. CRC Press, Inc., Boca Raton, FL.

2. Agarwal, V. K., and Sinclair, J. B. 1997. Deterioration of seeds by storage fungi. Pages 321361 in: Principles of Seed Pathology, 2nd ed. CRC Press, Inc., Boca Raton, FL.

3. Anonymous. 2003. International Phytosanitary Certificate No. 4051. Phytosanitary Federal Law of the Mexican United States, Phytosanitary Regulation and Inspection Department, Mexico.

4. Aveling, T. A. S., Snyman, H. G., and Maude, S. P. 1993. Evaluation of seed treatments for reducing Alternaria porri and Stemphylium vesicarium on onion seed. Plant Dis. 77:1009.

5. Correll, J. C., Morelock, T. E., Black, M. C., Koike, S. T., Brandenberger, L. P., and Dai- 
nello, F. J. 1994. Economically important diseases of spinach. Plant Dis. 78:653-660.

6. du Toit, L. J., and Derie, M. L. 2001. Stemphylium botryosum pathogenic on spinach seed crops in Washington. Plant Dis. 85:920.

7. du Toit, L. J., and Derie, M. L. 2002. Leaf spot of spinach seed crops in Washington State. (Abstr.) Phytopathology 92:S21.

8. du Toit, L. J., and Derie, M. L. 2003. Inoculum sources of Stemphylium botryosum and Cladosporium variabile in spinach seed crops. (Abstr.) Phytopathology 93:S22.

9. du Toit, L. J., Derie, M. L., and HernandezPerez, P. 2004. Evaluation of fungicides for control of leaf spot in spinach seed crops, 2003. Fungic. Nematicide Tests 59:V115.

10. du Toit, L. J., Derie, M. L., and HernandezPerez, P. 2005. Evaluation of fungicides for control of leaf spot in spinach seed crops, 2004. Fungic. Nematicide Tests 60:V044

11. du Toit, L. J., Derie, M. L., and HernandezPerez, P. 2005. Evaluation of yield loss caused by leaf spot fungi in spinach seed crops, 2004. Fungic. Nematicide Tests 60:V047.

12. du Toit, L. J., Derie, M. L., and HernándezPérez, P. 2005. Verticillium wilt in spinach seed production. Plant Dis. 89:4-11.

13. Everts, K. L., and Armentrout, D. K. 2001. Report of leaf spot of spinach caused by Stemphylium botryosum in Maryland and Delaware. Plant Dis. 85:1209.

14. Foss, C. R., and Jones, L. J. 2005. Crop Profile for Spinach Seed in Washington. United States Department of Agriculture National Pest Management Centers.

15. Fuentes-Davila, G. 1988. Studies on a leaf spot disease of spinach caused by Cladosporium variable (Cooke) de Vries. Ph.D. thesis. Washington State University, Pullman.

16. Hansen, H. R., Weber, A., and Kristensen, H. R. 1952. Plant diseases in Denmark in 1950. Annual survey compiled by the State Phytopathological Experiment Station. (Abstr.) Tidsskr. Planteavl. 56:1-59. (Translated in Rev. Appl. Mycol. 32:234.)

17. Hermansen, A., Brodal, G., and Balvoll, G. 2000. Hot water treatment of carrot seeds: Ef- fects on seed-borne fungi, germination, emergence and yield. Seed Sci. Technol. 27:599613.

18. Hernandez-Perez, P. 2005. Management of seedborne Stemphylium botryosum and Cladosporium variabile causing leaf spot of spinach seed crops in western Washington. M.S. thesis. Washington State University, Pullman.

19. Hernandez-Perez, P., and du Toit, L. J. 2005. Efficacy of chlorine and hot water seed treatments for control of Cladosporium, Stemphylium, and Verticillium in spinach. (Abstr.) Phytopathology 95:S41.

20. Hernandez-Perez, P., and du Toit, L. J. 2005. Prevalence of Stemphylium botryosum and Cladosporium variabile in commercial spinach seed, and their potential for seed transmission. (Abstr.) Phytopathology 95:S41.

21. Hochmuth, G. J., Vavrina, C. S., Stall, W. M., and Kucharek, T. A. 2004. Spinach production in Florida. Pages 273-275 in: Vegetable Production Handbook for Florida. Hortic. Sci. Dep. HS735, Univ. Fla. IFAS, Fla. Coop. Ext. Serv. Gainesville.

22. Inaba, T., Takahashi, K., and Morinaka, T. 1983. Seed transmission of spinach downy mildew. Plant Dis. 67:1139-1141.

23. Inglis, D. A., Derie, M. L., and Gabrielson, R. L. 1997. Cladosporium leaf spot on spinach seed crops and control measures. Wash. State Univ. Ext. Bull. No. 865, Pullman

24. Koike, S. T. 2000. Spinach production and pest management in California. Pages 12-13 in: Abstr. Nat. Spinach Conf. San Antonio, TX

25. Koike, S. T., Henderson, D. M., and Butler, E. E. 2001. Leaf spot disease of spinach in California caused by Stemphylium botryosum. Plant Dis. 85:126-130.

26. Maude, R. B. 1996. Disease control: Eradication and reduction of inoculum by seed treatment. Pages 114-178 in: Seedborne Diseases and Their Control. Principles and Practice. CAB International, Oxon, UK.

27. Maynard, D. N., and Hochmuth, G. J. 1997. Knott's Handbook for Vegetable Growers, 4th ed. John Wiley \& Sons, Inc., New York.
28. Neergaard, P. 1977. Seed treatment, procedures and equipment. Pages 595-613 in: Seed Pathology, Vol. I. John Wiley \& Sons, New York.

29. Nega, E., Ulrich, R., Werner, S., and Jahn, M. 2003. Hot water treatment of vegetable seed An alternative seed treatment method to control seed-borne pathogens in organic farming J. Plant Dis. Prot. 10:220-234.

30. Pryor, B. M., Davis, R. M., and Gilbertson, R L. 1994. Detection and eradication of Alternaria radicina on carrot seed. Plant Dis. 78:452-456.

31. Raid, R. N. 2004. Management of Stemphylium leaf spot in baby spinach harvested for spring mix production in the Everglades agricultural area of Florida. Page 24 in: Proc. 17th Int. Lettuce Leafy Veg. Conf. Quebec, Canada.

32. Raid, R. N, and Kucharek, T. 2003. 2003 Florida Plant Disease Management Guide: Spinach. University of Florida, Gainesville.

33. Snyder, W. C., and Wilhelm, S. 1962. Seed transmission of Verticillium wilt of spinach. (Abstr.) Phytopathology 52:365.

34. Steele, R. G. D., and Torrie, J. H. 1980. Principles and Procedures of Statistics: A Biometrical Approach, 2nd ed. McGraw Hill, New York

35. Strandberg, J. O. 1988. Detection of Alternaria dauci on carrot seed. Plant Dis. 72:531-534.

36. Standberg, J. O., and White, J. M. 1989. Response of carrot seeds to heat treatments. J. Am. Soc. Hortic. Sci. 114:766-769.

37. van der Spek, J. 1972. Internal carriage of Verticillium dahliae by seeds and its consequence. Meded. Fac. Landbouwwet. Rijksuniv. Gent. 37:567-573.

38. van der Spek, J. 1973. Seed transmission of Verticillium dahliae. Meded. Fac. Landbouwwet. Rijksuniv. Gent. 38:1427-1434.

39. Yaklich, R. W. 1985. Germination tests. Pages 30-36 in: Rules for Testing Seeds. Association of Official Seed Analysts. J. Seed Technol. 8:2.

40. Yang, Y., Kim, K. S., and Anderson, E. J. 1997. Seed transmission of cucumber mosaic virus in spinach. Phytopathology 87:924-931. 